\title{
p53-Independent checkpoint controls in a plant cell model
}

\author{
HELVIA R PELAYO ${ }^{1,2}$, JUANA PINCHEIRA ${ }^{3}$, JUAN F GIMÉNEZ-ABIÁN ${ }^{1}$, DUNCAN J \\ CLARKE $^{4}$ and CONSUELO DE LA TORRE ${ }^{1}$
}

\author{
${ }^{1}$ Centro de Investigaciones Biológicas, CSIC. Madrid, Spain \\ ${ }^{2}$ Universidad de Ciudad Juárez, Chihuahua, México \\ ${ }^{3}$ Programa de Genética Humana, ICBM, Facultad de Medicina, Universidad de Chile, Santiago, Chile \\ ${ }^{4}$ University of Minnesota Medical School, Department of Genetics, Cell Biology \& Development, \\ Minneapolis, MN 55455, U.S.A.
}

\begin{abstract}
Allium cepa L. meristems were used as a plant model to study the p53-independent control of S and G2 phases by checkpoint pathways, in eukaryotic cells. Checkpoint blocks were induced at early and mid $\mathrm{S}$ by hydroxyurea. After their spontaneous override, cells became accumulated in G2-prophase, giving rise later on to a delayed mitotic wave. Cell growth was maintained during the checkpoint blocks, as the delayed mitoses were larger in size than the control ones. Under continuous hydroxyurea treatment, the delayed mitotic was formed by two subpopulations: normal mitoses corresponding to cells having properly recovered from the checkpoint block, and abnormal ones resulting from checkpoint adaptation. These latter cells displayed broken chromatids as they had unduly overriden the G2 checkpoint block, without completing DNA repair. The frequency of the checkpointadapted mitoses increased with the hydroxyurea concentration from 0.25 to $1.0 \mathrm{mM}$. However, from $1 \mathrm{mM}$ hydroxyurea upwards, some of the cells lost their competence for checkpoint adaptation. Therefore, the dose of a genotoxic agent that still allows G2 checkpoint adaptation should always be applied in order to get rid of uncontrolled proliferating cells. This is specially suitable for cells lacking a functional p53 protein.
\end{abstract}

Key terms: Checkpoint adaptation; Hydroxyurea; S and G2 checkpoints; p53-independent checkpoints; Allium cepa L. meristems.

\section{INTRODUCTION}

Most of the checkpoint proteins responsible for the transduction of antimitogenic signals which prevent an irreversible cycle phase transition, before some crucial requirement is fulfilled, are conserved in eukaryotes. Thus, the codifying gene for the kinase mutated in patients with ataxia telangiectasia (ATM) is also present in plants (García et al., 2000). This kinase activates the $\mathrm{Cdc} 25$ phosphatase that, in turn, activates the cyclin-dependent kinases (CDKs), by removing the inhibitory phosphorylations in the CDK threonine 14 -tyrosine 15 residues. These residues behave as a molecular switch which alternatively activates or brakes cycle progression. There is no $\mathrm{Cdc} 25$ sequence homologue in plants. However, some functional homologue of this phosphatase should be present in plants, as dephosphorylation of the CDK inhibitory phosphoresidues also takes place in response to cytokinin activation (Reichheld et al., 1999).

The universality of the genes that stimulate proliferation ( $\mathrm{Cdc}$ genes, protooncogenes) and also those that brake it (Chk or checkpoint genes, tumor suppresor genes) justify the use of different eukaryotic model systems to deal with still uncertain features of the proliferation control.

Sequential waves of different CDKs complexed with different regulatory cyclins promote cycle progression throughout the different cycle phase transitions (Pines and Rieder, 2001). In plants, the functional homologue of the animal Cdk1 is CdkA, while there are two $\mathrm{CdkB} 1$ and $\mathrm{CdkB} 2$ 
groups not present in animal cells (Joubès et al., 2000). In relation to cyclins, plants possess three A-type and two B-type cyclin groups (Renaudin et al., 1998). Expression of both B-type cyclins are restricted to late G2 and mitosis (Hirt et al., 1992; Fobert et al., 1994). Plant cyclin B2 seems to be the homologue of the mammalian cyclin A. During G2, it is expressed before cyclin B1. Cyclin B2 seems to be the target of the checkpoint control pathways operating in G2 and early mitosis (Weingartner et al., 2003). The ectopic expression of cyclin B2 induces the override of the G2 checkpoint that surveys the irreversible entry into mitosis when activated by topoisomerase II inhibition (Giménez-Abián et al., 2002).

Root meristems can be used to study the behaviour of the eukaryotic proliferating cells. They keep a convenient proliferation fraction (close to 1.0), and maintain all the checkpoints intact, in contrast to immortalized cells. Moreover, as the checkpoint or tumor suppressor protein p53 has not been detected in plants (Arabidopsis Genome Initiative, 2000; Vandepoele et al., 2002), the plant cells here used can be considered as a suitable model for studying the p53-independent control of proliferation. This is also the case in nearly $50 \%$ of tumoral mammalian cells (LópezSaéz et al., 1998).

In the present work, we have followed $\mathrm{S}$ checkpoints activated by hydroxyurea and the subsequent G2 checkpoint in Allium cepa L. plant meristems. The depletion that this drug induces in deoxyribonucleotides, by blocking the ribonucleotide reductase (Graslund, 2002), challenges the intra-S or replication checkpoints and, also, the $\mathrm{G} 2$ checkpoint in sequence (Pelayo et al., 2001).

The checkpoint pathways transduce antimitogenic signals that provide the proliferating cell with additional time to accomplish a necessary requirement before the irreversible transition to a subsequent cycle phase. Thus, they prevent G2 cells entering mitosis until the completion of DNA replication and post-replication repair are completed (Melo and Toczyski, 2002; Samuel et al., 2002).
The arrest in cycle progression provided by a checkpoint is always transient, either due to cell recovery (fulfilment of the requirement) or to checkpoint adaptation. In this latter process, the cell spontaneously continues cycle progression despite unfulfilment of the checkpoint requirement. Checkpoint adaptation is often followed by genome instability, allowing cell survival at the cost of tolerating mutation.

The fates of both the recovered and the checkpoint-adapted cells were followed during the continuous presence of different $\mathrm{HU}$ concentrations. Cells lost their capability to recover and become checkpoint-adapted when overriding a certain treatment concentration threshold.

\section{MATERIAL AND METHODS}

Bulbs of Allium cepa L. cv. Francesa were obtained in the local market. The bulb scales were removed and, after washing the bulbs, their crowns where root blastema are located were placed on $90-\mathrm{ml}$ glass tubes filled with filtered tap water. The water was continuously aerated by bubbling air at $10-20 \mathrm{ml} / \mathrm{min}$. They were kept in dark growth incubators at $25 \pm 0.5{ }^{\circ} \mathrm{C}$. The filtered tap water was renewed every $24 \mathrm{~h}$, while drug treatments were changed at 8 or $12 \mathrm{~h}$ intervals. Two or three days after initiating the cultures, bulbs with more than 40 roots were selected. Each bulb was cut in two halves, and the cut surfaces were extensively washed in filtered tap water. Before any treatment was initiated, each half-bulb was again cultured for at least $8 \mathrm{~h}$ under control conditions. Each half-bulb was placed on a new culture tube containing either the control or the other experimental solutions. Hydroxyurea (Sigma) solutions were freshly prepared in filtered tap water previously warmed to $25^{\circ} \mathrm{C}$.

\section{Isolation of nuclei}

Nuclei were isolated as described by Lucretti and Dolezel (1995) with minor modifications. Briefly, one millimeter long root segments corresponding to 0.5 to 1.5 
$\mathrm{mm}$ from the root tip were fixed for $20 \mathrm{~min}$ at $4{ }^{\circ} \mathrm{C}$ in $4 \%$ (v/v) formaldehyde in Tris buffer $(10 \mathrm{mM}$ Tris, $10 \mathrm{mM}$ EDTA, 100 $\mathrm{mM} \mathrm{NaCl}, \mathrm{pH} 7.5$ ) containing $0.1 \%$ Triton $\mathrm{X}-100$. After fixation, samples were washed three times with Tris buffer. Segments from the meristems were homogenised in lysis buffer (15 mM Tris, $2 \mathrm{mM}$ EDTA, $80 \mathrm{mM}$ $\mathrm{KCl}, 20 \mathrm{mM} \mathrm{NaCl}$ and 0.1 Triton $\mathrm{X}-100$, $\mathrm{pH} 7.5)$, using a dispersing homogeneiser (Ultra Turrax T20, 25N-8, IKA, Germany). After mincing, homogenates were filtered through a $50 \mu \mathrm{m}$ stainless-steal mesh. The nuclear suspensions obtained were centrifuged at $600 \mathrm{~g}$ for $20 \mathrm{~min}$ at $4{ }^{\circ} \mathrm{C}$. Then supernatants were removed and the pellets were resuspended in the lysis buffer and maintained at $4{ }^{\circ} \mathrm{C}$ until the flow cytometry analyses were performed. At each fixation time, a total number of 10,000 nuclei were studied by flow cytometry.

\section{Isolation of cells and recording of cell size}

In order to record cell size by flow cytometry, whole cells were isolated from root segments previously fixed for one hour. The protocol for isolation of nuclei was followed. However, after washing with the Tris buffer, $10 \mathrm{mM}$ citrate buffer $\mathrm{pH} 4.8$ was added for cell isolation. The Tris buffer was again used 3 times, before adding the lysis buffer at $\mathrm{pH}$ 4.8. Cell size was evaluated by recording light scatter values by flow cytometry. At the same time, the relative amount of DNA was estimated, after propidium iodide (PI) staining of nuclei. These values were used to estimate the cell size to nuclear DNA content ratios.

\section{Flow cytometry}

DNA content was estimated after PI staining and flow cytometry analysis. Samples were incubated with RNase A (BoehringerMannheim) at $30 \mu \mathrm{g} / \mathrm{ml}$ (equivalent to 1.5 i.u. per sample), and propidium iodide (Sigma) at $100 \mu \mathrm{g} / \mathrm{ml}$, for $30 \mathrm{~min}$ at room temperature. Flow cytometry analysis was carried out with an EPICs XL analyzer (Coulter, Dunstable, UK), equipped with an ion argon laser tuned at $488 \mathrm{~nm}$. Fluorescent signals from the PI-labelled nuclei were collected by a 525-nm BP filter and a 620-nm BP filter (both from Zeiss), respectively. For DNA content analysis, doublets and larger aggregates were discarded by electronic analysis of integraland height-signals from the particles analyzed.

\section{Conventional optical microscopy}

Mitotic index and the frequency of metaphases and telophases with and without chromatid breaks were recorded in root tips fixed overnight in $3: 1(\mathrm{v} / \mathrm{v})$ ethanolacetic acid, and then stained with acetic orcein. An average of 6,000 cells were scored at each treatment, from at least three roots of different bulbs. The ratio of normal to aberrant anaphases-telophases was also estimated.

RESULTS

The effect of hydroxyurea on DNA replication and on cell size

The cell distribution in relation to DNA content in the cells that were kept in the continuous presence of $0.75 \mathrm{mM} \mathrm{HU}$ (treatment renewed every $8 \mathrm{~h}$ to exclude HU breakdown) is presented in Figure 1. It shows that DNA synthesis was reinitiated within $10 \mathrm{~h}$ of continuous HU treatment, when some cells reached a bulk DNA content close to $3 \mathrm{C}$. There is a second replication checkpoint in this mid $\mathrm{S}$ position, where cells accumulate again (Pelayo et al., 2001).

The cell size (light scattering) and nuclear DNA contents (propidium iodide signal) obtained by flow cytometry were used to estimate the cell size to DNA content ratio in meristems treated with hydroxyurea for $14 \mathrm{~h}$ (equivalent to one cell cycle time in control conditions), as well as in control meristems. The cell size to DNA content ratios were similar in the non-replicating $2 \mathrm{C}$ cells of HU-treated and untreated meristems (Fig. 2). However, the cells with 


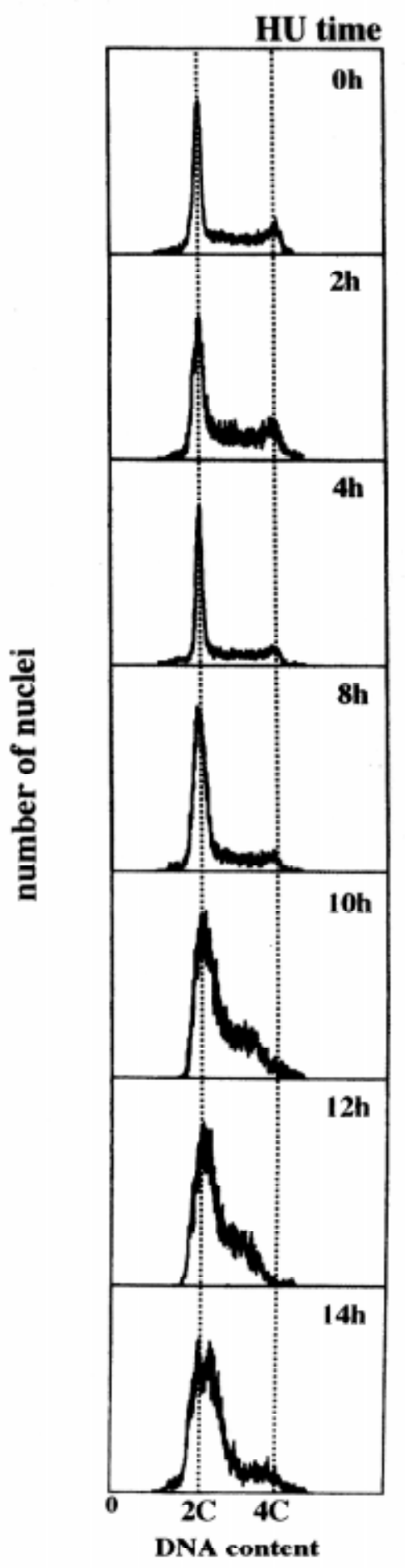

Fig. 1. Cell distribution at different times of $0.75 \mathrm{mM} \mathrm{HU}$ treatment in relation to DNA content, assessed by the propidium iodide incorporated by their nuclei. Asymmetry between both slopes of the $2 \mathrm{C}$ peak becomes detectable at the hour 10 . The checkpoint override of the HU-induced early $\mathrm{S}$ block starts to occur in some cells of the population at that time, when cells with a DNA content around 3C accumulate. At the $14^{\text {th }} \mathrm{h}$, the cell accumulation in mid $\mathrm{S}$ is also overriden.
DNA values between 2 and $4 \mathrm{C}$ displayed a greater size to DNA content ratio in the HU-treated cells than in the controls. This means that the cells accumulated in the $\mathrm{S}$ phase in the presence of HU endured continuous cell growth while their DNA replication was checkpoint-blocked.

The delayed appearance of a mitotic wave

The frequency of mitoses with and without broken chromatids (abnormal and normal mitoses, respectively) were scored in cells in the continuous presence of $0.75 \mathrm{mM} \mathrm{HU}$. HU produced a continuous fall in the mitotic index (MI) up to the $10 \mathrm{~h}$ of treatment, when the MI was closest to zero (Fig. 3). MI started to rise again mostly from the 28 $\mathrm{h}$ onwards of the continuous HU treatment. The frequency of the normal mitoses in the 36 to $42 \mathrm{~h}$ of hydroxyurea reached a value higher than the normal frequency of mitotic cells found in controls, at the $0 \mathrm{~h}$.

From 16 to $34 \mathrm{~h}$ of HU treatment, most of the mitotic cells were abnormal, i.e. they displayed chromosomes with chromatid breaks. This observation directly proves that these latter cells were adapted to the G2 DNA damage checkpoint. On the other hand, in the interval between 36 to $42 \mathrm{~h}$, the frequency of normal mitoses (with apparently intact chromosomes) rose over the frequency of the abnormal ones. This increment in normal mitoses corresponds to cells that have recovered from the HUinduced chromosomal damage during either the replication or $\mathrm{G} 2$ checkpoint-induced cycle blocks. It is surprising that such a recovery could take place in the continuous presence of $\mathrm{HU}$.

Effect of HU concentration on the frequency of $G 2$ checkpoint-adapted cells in the delayed mitotic wave

In order to determine whether there is any effect of the HU concentration on the chromosomal damage in the abnormal mitotic cells, the frequency of mitoses with chromosomal aberrations was estimated, under six different HU concentrations $(0.25$ 
non replicating nuclei (2C)

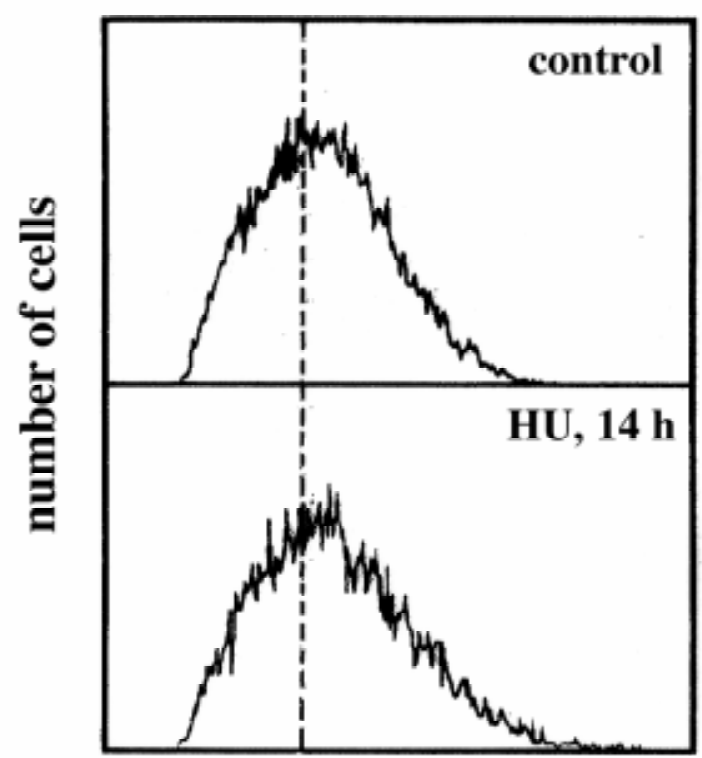

replicating nuclei (between 2C and 4C)

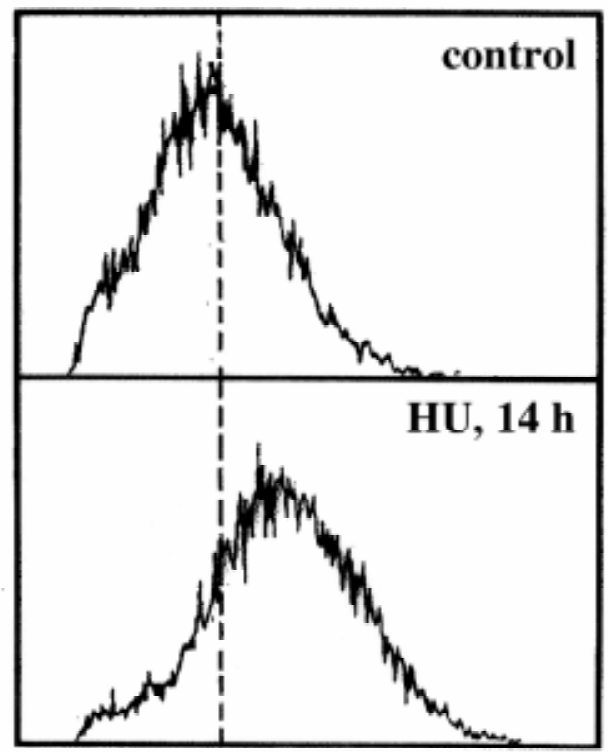

\section{cell size / DNA content}

Fig. 2. Comparison of cell distribution at different cell size to nuclear DNA content ratios, in HU-treated and untreated cells. Left panels show the values corresponding to non-replicating G0 and G1 cells. Those corresponding to replicating cells are in the rigth panels. The discontinuous vertical lines indicate the mean values recorded in the controls.

to $1.5 \mathrm{mM})$, at 26,32 and $38 \mathrm{~h}$ of continuous HU treatment. At these three treatment times, there was a positive linear correlation $(\mathrm{r}=0.9995 ; 0.9885$ and 0.990 , respectively $)$ between the frequency of mitotic cells with chromosomal aberrations and the HU concentration, between 0.25 and $1.0 \mathrm{mM}$ (Table I). The maximum frequency of mitoses with broken chromatids (98.3\%) was recorded at $1.0 \mathrm{mM} \mathrm{HU}, 26 \mathrm{~h}$ after the HU treatment had been initiated. The delay in appearing such a late mitotic wave was independent from the HU concentration, at least in the 0.25 to $1.5 \mathrm{mM}$ range (data not shown).

At all concentrations assayed, the frequency of mitoses with broken chromatids fell progressively down from the 26 to the $38 \mathrm{~h}$ of recovery. Strikingly, the abnormal to normal mitoses ratio decreased with the dose in the 1.25 and $1.5 \mathrm{mM} \mathrm{HU}$ treatments, when compared to the values obtained at 1.0 mM HU (Table I). However, the frequency of normal mitoses remained steady when compared to those found at $1 \mathrm{mM} \mathrm{HU}$ concentration (data not shown). Therefore, some of the cells that should have entered into the delayed wave of mitoses lost their competence for checkpoint-adaptation over a certain damage threshold.

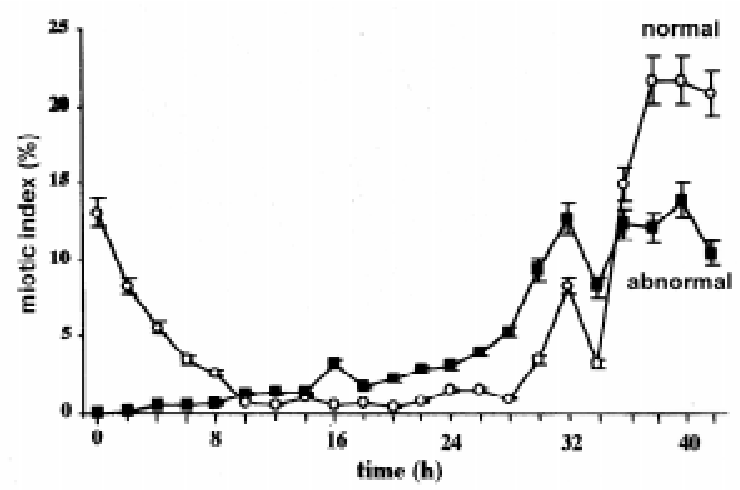

Fig. 3. Mitotic index for normal (open circles) and abnormal mitoses (closed squares) recorded under $0.75 \mathrm{mM}$ HU. The presence of chromatid breaks in the abnormal mitoses indicates that these cells have endured adaptation at least to the DNA damage checkpoint in G2 and, probably, to the replication checkpoints. For any time point, the total mitotic index corresponds to the sum of the frequencies of both normal and abnormal mitoses. From the 16 to $34 \mathrm{~h}$ of HU treatment, the frequency of abnormal mitoses was higher than that of normal ones. The trend was reversed from later times ( 36 to $40 \mathrm{~h}$ ). 
TABLE I

Frequency of the checkpoint-adapted mitoses (i.e. those with chromosomal aberrations) at different $\mathrm{HU}$ concentrations (mean $\pm \mathrm{SD}$ )

\begin{tabular}{ccccccc}
\hline $\begin{array}{c}\text { Treatment } \\
\text { duration, } \mathrm{h}\end{array}$ & \multicolumn{5}{c}{ HU concentration, mM } \\
\hline & 0.25 & 0.50 & 0.75 & 1.0 & 1.25 & 1.5 \\
26 & $26.1 \pm 2.3$ & $48.3 \pm 4.0$ & $72.9 \pm 6.4$ & $98.3 \pm 8.6$ & $63.0 \pm 5.1$ & $20.1 \pm 1.8$ \\
32 & $20.3 \pm 4.1$ & $31.8 \pm 2.4$ & $60.2 \pm 5.3$ & $78.6 \pm 6.4$ & $56.4 \pm 4.7$ & $16.2 \pm 2.8$ \\
38 & $12.9 \pm 1.2$ & $26.1 \pm 1.9$ & $36.4 \pm 3.5$ & $43.2 \pm 3.8$ & $29.6 \pm 3.2$ & $8.7 \pm 1.3$ \\
\hline
\end{tabular}

\section{DISCUSSION}

Redundant checkpoint pathways control common cycle phase transitions both in yeast (De la Torre-Ruiz et al., 1998), in human (Passalaris et al., 1999) and in plant cells (Pelayo et al., 2001). These latter cells provide a valid model for studying the p53-independent control of G2 that could also apply to $50 \%$ of the mammalian transformed cells that lack a functional p53 checkpoint protein.

All checkpoint pathways incorporate different inputs to give rise later to a single mitogenic/antimitogenic output. Cell size is one of such checkpoint inputs. An enlarged size provides an excess of mitogenic signals. Cell enlargement promotes the override of the pheromoneinduced G1 checkpoint block that makes $S$. pombe mating partners competent for conjugation (Stern and Nurse, 1997). The inputs on excessive cell size may not be restricted to $\mathrm{G} 1$ and $\mathrm{G} 2$ phases. The enlargement recorded in the plant cells that resumed DNA replication in the presence of HU supports that it also applies to the intra-S checkpoints. As a result of the checkpoint operation, there would be a cross-talk between the mitogenic signals, produced by continuing cell growth, and the antimitogenic ones, produced by the replication forks that are stalled in the $\mathrm{HU}$ presence.

Adaptation to intra-S checkpoint blocks can be possible in the continous presence of $\mathrm{HU}$ if the nucleotide pool rise is due to the upregulation of the ribonucleotide reductase genes (Elledge et al., 1993).
Cell subpopulation recovered from checkpoint blocks

The additional time needed by proliferating cells to accomplish any missing task before a phase transition, that is provided by a transient checkpoint block, can be called acclimation time. This term is borrowed from the adaptive response to environmental stress. The present results show that cells transiently blocked by an intra $\mathrm{S}$ checkpoint activated by $\mathrm{HU}$ are able to complete both their DNA synthesis and their post-replication repair. These cells enter into mitosis with all their chromosomes apparently intact, and then are indistinguishable from controls (Pelayo et al., 2001). Such cell subpopulation apparently recovers from the stress produced by nucleotide depletion which is the main objective of the replication checkpoint pathway (Desany et al., 1998).

\section{Checkpoint-adapted cells}

The proper HU recovery response is different from checkpoint adaptation. Instauration of alternative unconventional routes (Kohn, 1999) permits the fulfilment of the missing requirement. Checkpoint override before fulfilment of a requirement offers the cell the option to remain viable at the expense of its genome instability (McClintock, 1984).

Cells unable to perform checkpoint adaptation may instead induce a program of cell death (apoptosis), or may simply fail to proliferate, remaining quiescent. Re- 
initiation of proliferation in them is responsible for tumor growth relapse.The present data suggests that the choice of alternative outcomes depends on the stress intensity, a function of the type and amount of cell damage. Thus, over a certain threshold, the frequency of cells unable to become checkpoint-adapted increased with the HU concentration.

The induction of checkpoint-adaptation potentiates the damaging effect of the genotoxic agents used in cancer therapy (Ghosh et al., 1997). As this work shows, the concentration of the genotoxic agent determines the amount of cells that endure checkpoint adaptation. Therefore, the determination of the maximum concentration of a genotoxic treatment that still allows checkpoint adaptation is needed to optimize it in order to get rid of transformed cells.

\section{ACKNOWLEDGMENTS}

We thank Ms. M. Carrascosa and Mr. J.L. Marcilla for their excellent technical contribution and Mrs. Beryl L. Walker for correcting the English. The work has been partially supported by the Dirección General de Investigación del Ministerio de Ciencia y Tecnología de España (Project BMC2001-2195), by the MecesupPostgrado UCH de Chile (Project 9903). We thank the Agencia Española de Cooperación Internacional del Ministerio de Asuntos Exteriores de España for a fellowship granted to H.R.P.

\section{REFERENCES}

ARABIDOPSIS GENOME INITIATIVE (2000) Analysis of the genome sequence of the flowering plant Arabidopsis thaliana. Nature 408: 796-815

DE LA TORRE-RUIZ M, GREEN CM, LOUNDES NF (1998) RAD9 and RAD24 define two additive, interacting branches of the DNA damage checkpoint pathway in budding yeast normally required for Rad53 modification and activation. EMBO J 17: 2687-2698

DESANY BA, ALCASABAS AA, BACHANT JB, ELLEDGE SJ (1998) Recovery from DNA replicational stress is the essential function of the Sphase checkpoint pathway. Genes Dev 12: 2956-2970
ELLEDGE SJ, ZHOU Z, ALLEN JB, NAVAS TA (1993) DNA damage and cell cycle regulation of ribonucleotide reductase. Bioessays 15: 333-339

FOBERT PR, COEN ES, MURPHY GJ, DOONAN JH (1994) Patterns of cell division revealed by transcriptional regulation of genes during the cell cycle in plants. EMBO J 13: 616-624

GARCIA V, SALANOUBAT M, CHOISNE N, TISSIER A (2000) An ATM homologue from Arabidopsis thaliana: complete genomic organisation and expression analysis. Nucleic Acids Res 28: 16921699

GHOSH S, PAWELETZ N, SCHROETER D (1997) Induction of premature mitosis in cells blocked in $\mathrm{S}$ phase: possibilities of its use in cancer therapy. Anticancer Res 17: 2357-2361

GIMÉNEZ-ABIAN JF, WEINGARTNER M, BINAROVA P, CLARKE DJ, ANTHONY RG, CALDERINI O, HEBERLE-BORS E, MORENO DIAZ DE LA ESPINA S, BÖGRE L, DE LA TORRE C (2002) A topoisomerase II-dependent checkpoint in G2-phase plant cells can be bypassed by ectopic expression of mitotic cyclin B2. Cell Cycle 1: 187-192

GRASLUND A (2002) Ribonucleotide reductase: kinetic methods for demonstrating radical transfer pathway in protein $\mathrm{R} 2$ of mouse enzyme in generation of tyrosil free radical. Methods Enzymol 354: 399-414

HIRT H, MINK M, PFOSSER M, BÖGRE L, GYORGYEY J, JONAK C, GARTNER A, DUDITS D, HEBERLEBORS E (1992) Alfalfa cyclins: differential expression during the cell cycle and in plant organs. Plant Cell 4: 1531-1538

JOUBÈS J, CHEVALIER C, DUDITS D, HEBERLE-BORS E, INZÉ D, UMEDA M, RENAUDIN JP (2000) CDKrelated protein kinases in plants. Plant Mol Biol 43: 607-620

KOHN K (1999) Molecular interaction map of the mammalian cell cycle control and DNA repair systems. Mol Biol Cell 10: 2703-2734

LÓPEZ-SÁEZ JF, DE LA TORRE C, PINCHEIRA J; GIMENEZ-MARTIN G (1998) Cell proliferation and cancer (Review). Histol Histopathol 13: 1197-1214

LUCRETTI S, DOLEZEL J (1995) Cell synchronisation, chromosome isolation and flow sorting in plants. In: Galbraith DV, Bohnert H, Bouque DP,eds. Methods in Cell Biology. Plant Cell Biology. Orlando FL, USA: Academic Press

McCLINTOCK B (1984) The significance of responses of the genome to challenge. Science 226: 792-801

MELO J, TOCZYSKI D (2002) A unified view of the DNA-damage checkpoint. Curr Op Cell Biol 14: 237 245

PASSALARIS TM, BENANTI JA, GEWIN L, KIYONO T, GALLOWAY DA (1999) The G2 checkpoint is maintained by redundant pathways. Mol Cell Biol 19: 5872-5881

PELAYO HR, LASTRES P, DE LA TORRE C (2001) Replication and G2 checkpoints: their response to caffeine. Planta 212: 444-453

PINES J, RIEDER CL (2001) Re-staging mitosis: a contemporary view of mitotic progression. Nat Cell Biol 3: E3-E6

REICHHELD JP, VERNOUX T, LARDON F, VAN MONTAGU M, INZË D (1999) Specific checkpoints regulate plant cell cycle progression in response to oxidative stress. Plant J 17, 647-656 
RENAUDIN JP, SAVOURE A, PHILIPPE H, VAN MONTAGU M, INZË D, ROUZÉ P (1998) Characterization and classification of plant cyclin sequences related to A- and B-type cyclins. Plant Cell Division 10: 67-98

SAMUEL T, WEBER HO, FUNK JO (2002) Linking DNA damage to cell cycle checkpoints. Cell Cycle 1: 162168

STERN B, NURSE P (1997) Fission yeast pheromone blocks S-phase by inhibiting the G1 cyclin B-p34cdc2 kinase. EMBO J. 16: 534-544
VANDEPOELE K, RAES J, DE VEYLDER L, ROUZÉ P, ROMBAUTS S, INZË D (2002) Genome-wide analysis of core cell cycle genes in Arabidopsis. Plant Cell 14: 903-916

WEINGARTNER M, PELAYO HR, BINAROVA P, ZWERGER K, MELIKANT B, DE LA TORRE C, HEBERLE-BORS E, BOGRE L (2003) A plant cyclin B2 is degraded early in mitosis and its ectopic expression shortens G2-phase and alleviates the DNAdamage checkpoint. J. Cell Sci. 116: 487-498 